\title{
Corrigendum
}

\section{Party System Nationalization and the Provision of Public Health Services-CORRIGENDUM}

\author{
ALLEN HICKEN, KEN KOLLMAN AND JOEL W. SIMMONS
}

doi: http://dx.doi.org/10.1017/psrm.2015.41. Published online by Cambridge University Press, 20 August, 2015.

In the original publication of this article, the link to view supplementary material was given incorrectly. The correct link is: https://sites.google.com/site/joelsimmons/.

The authors apologise for this error.

\section{REFERENCE}

Hicken, Allen, Ken Kollman, and Joel W. Simmons. 'Party System Nationalization and the Provision of Public Health Services'. Political Science Research and Methods, available on CJO2015. doi:10.1017/psrm.2015.41. 